paratively recently that a scientific Press serving the non-specialist has appeared. For the general public, most newspapers now have on their staffs journalists, some of considerable merit, who regularly report on the progress of science. It is to be expected that, though their reporting is usually accurate, it is often highly coloured and somewhat exaggerated to cater for popular taste. However, between the two extremes of the specialist and the general newspaper reader, there is a large public consisting of educated laymen with wide interests who require something which is more detailed than the newspapers can give but which, while presented in a serious, authoritative, concise and interesting manner, should yet avoid the terminology and preciseness of the specialist article.

In June 1946 the first number of "Science News" appeared, and it was at once acclaimed as a welcome and important addition to the then available scientific literature. It satisfied the particular and peculiar need of the specialist interested in what is going on in branches of science other than his own, and of the educated layman. The fact that No. I has since been followed at brief intervals within the past five years by no less than eighteen further issues in the series is sufficient indication of their considerable popularity and undoubted success. The publishers are to be congratulated on their enterprise, and the editor, Dr. J. L. Crammer, for devoting his spare time and considerable energy to the promotion of such a worthy object and with such remarkable success. No. 19 in the series of "Science News" (Harmondsworth: Penguin Books, Ltd., 1951; 1s. 6d.) records that a new editor has been appointed, namely, A. W. Haslett, who, as a frequent contributor to "Science News", the editor of the weekly Science To-day, science broadcaster and author, is well known as a science journalist. His wide knowledge, his many contacts in the universities and research laboratories and his deep apprecia. tion of scientific truth are particularly mentioned in the editorial of No. 19 as qualities which will ensure that under his guidance "Science News" will maintain its already high standard.

\section{Lord Rutherford: An Appreciation}

THE text of the Fifth Rutherford Lecture of the Physical Society, delivered before the Society by Dr. A. S. Russell, of Christ Church, Oxford, on December 8, 1950, has recently been published (Proc. Phys. Soc., A, 64, 217 ; March 1951). Describing himself as an inorganic chemist and a former pupil and admirer of Lord Rutherford, Dr. Russell not only gives his impressions of Rutherford as a man and physicist, but attempts also to explain why it was that the inorganic chemists were so slow, in the years preceding 1914, in arriving at the conceptions of isotopes and atomic number. The years 1907-19 which Lord Rutherford spent at the University of Manchester are described as "the great middle period of Rutherford's life of discovery". Many famous physicists, including Chadwick, Darwin, Marsden, Nuttall, Robinson and the brilliant Moseley, were members of his staff. He had the co-operation for a time of Niels Bohr, and many notable men of science from other universities came for long or short periods to work with him at Manchester.

Dr. Russell refers only briefly to Rutherford's scientific achievements, for they have been described in detail elsewhere. It is, however, by well-chosen illustrations and anecdotes that Dr. Russell brings out clearly the remarkable qualities of the great man: Rutherford's foresight and penetration, in addition to good fortune; his insight into scientific problems ; his great experimental skill; his exuberance when off duty and his seriousness at work; and, over all, his kindness and generous outlook on life. Finally, Dr. Russell considers the general question of the paramount importance of the 'great man' in science. It is his belief that we cannot afford in science not to know anything that possibly can be discovered, and that in the pursuit of knowledge we cannot afford to do without the 'great man'. The team of talented workers may finally make some great contribution to science, but the more fundamental the science, Dr. Russell asserts, the greater is the need for the big advances which only great men can make. Rutherford "by probing the atom to its very depth not only revealed great truth and great beauty; he showed us by example what one man can do when he makes the most of his great gifts".

\section{Centaurus : a New Quarterly on the History of} Science and Medicine

AN indication of the steadily growing interest in the history of science and medicine is given by the appearance, in Denmark, of a new quarterly journal, Centaurus, an addition to the not very extended ranks of the periodical literature on these subjects. The journal is published by Ejnar Munksgaard, of Nörregade 6, Copenhagen, and the general editor is Joan Anker, director of the Scientific and Medical Department of Copenhagen University Library, who is assisted by a board that includes a number of associate editors drawn from various European countries, North America and elsewhere. The first two numbers contain thirteen original articles, rather more than half of which are of medical interest. Additional matter is included under the headings : varia, book reviews, list of books received, and obituaries. The quarterly is well printed on good paper and adequately illustrated. The editorial board appears to have set a high standard for this new publication, and it should receive a welcome in Great Britain. Of particular interest to British readers, whose linguistic attainments are generally more limited than those of Continental readers, is the fact that it is laid down that all articles must be written in one of three languages: English, French or German. In fact, five of the thirteen articles in Nos. I and 2 are written in English. The annual subscription, about 44s. post paid, at the current rate of exchange, seems reasonable for these times.

\section{Human and Natural Laws in China and the West}

In his Hobhouse Memorial Trust Lecture, delivered on May 23, 1950, at Bedford College, London, and now published (Hobhouse Lecture No. 20; pp. 44 ; London: Oxford University Press, 1951; 2s. $6 d$. net), Dr. Joseph Needham traces the development of the ideas of human law and the laws of Nature in Europe and then reviews Chinese thought on this subject, with the object of discovering whether there is anything which could properly be classed among the factors in Chinese civilization which inhibited the indigenous rise of modern science and technology. $\mathrm{He}$ concludes that the great distaste of the Chinese for precisely formulated, abstract, codified law, the relatively greater importance of the element of natural law in Chinese than in European society, and 